\title{
Post-Industrial Revolution changes in large-scale atmospheric pollution of the northern hemisphere by heavy metals as documented in central Greenland snow and ice
}

\author{
Jean-Pierre Candelone and Sungmin Hong \\ Laboratoire de Glaciologie et Geophysique de l'Environnement du Centre National de la Recherche Scientifique \\ Saint Martin d'Hères, France \\ Christian Pellone \\ Centre de Recherche et d'Essais des Machines Hydrauliques de Grenoble, Saint Martin d'Hères, France \\ Claude F. Boutron ${ }^{1}$ \\ Laboratoire de Glaciologie et Géophysique de l'Environnement du Centre National de la Recherche Scientifique \\ Saint Martin d'Hères, France
}

Abstract. $\mathrm{Pb}, \mathrm{Zn}, \mathrm{Cd}$ and $\mathrm{Cu}$ have been measured using ultraclean procedures in various sections of a $70.3-\mathrm{m}$ snow/ice core covering the past 220 years (including the Industrial Revolution) drilled at Summit, central Greenland. These time series are the first reliable ones ever published for $\mathrm{Zn}, \mathrm{Cd}$, and $\mathrm{Cu}$; for $\mathrm{Pb}$ they are the first verification of the pioneering data published more than two decades ago by $\mathrm{C}$. Patterson and his coworkers [Murozumi et al., 1969]. For all four heavy metals, concentrations are found to have markedly increased up until the 1960s and 1970s before decreasing significantly during the following few decades. The timing and the amplitude of the observed changes differ significantly however from one metal to another. Comparison with concentration values obtained by analyzing ancient Holocene ice dated 7760 years B.P., that is, before humans started to impact on the atmosphere, show that no detectable increase occurred for $\mathrm{Zn}, \mathrm{Cd}$, and $\mathrm{Cu}$ before the Industrial Revolution. On the other hand, $\mathrm{Pb}$ concentrations were already one order of magnitude above natural values in late 18th century ice. Cumulative deposition of heavy metals to the whole Greenland ice cap since the Industrial Revolution ranges from $3200 \mathrm{t}$ for $\mathrm{Pb}$ to $60 \mathrm{t}$ for $\mathrm{Cd}$.

\section{Introduction}

Investigating the occurrence of heavy metals in the wellpreserved dated snow and ice layers deposited in the large Greenland ice sheet during the last few centuries offers a unique way to reconstruct the history of the large-scale pollution of the atmosphere of the northern hemisphere for these toxic metals especially since the Industrial Revolution [Wolff and Peel, 1985; Peel, 1989; Wolff, 1990; Boutron et al., 1994, 1995].

This was first illustrated by C. Patterson and his coworkers in a pioneering paper published twenty five years ago [Murozumi et al., 1969]. Using revolutionary ultraclean sampling and laboratory techniques [Patterson and Settle, 1976], they obtained the first reliable time series for $\mathbf{P b}$ concentration in Greenland snow and ice for the 1753-1965 time period from the analysis of large-size snow blocks collected from the walls of shafts or trenches at two locations in north west Greenland: Camp Century $\left(77^{\circ} 10^{\prime} \mathrm{N}, 61^{\circ} 08^{\prime} \mathrm{W}\right.$, elevation $1866 \mathrm{~m}$ above sea level (a.s.l.)) and the "virgin trench site" $\left(76^{\circ} 46^{\prime} \mathrm{N}, 58^{\circ} 52^{\prime} \mathrm{W}\right.$, elevation $1800 \mathrm{~m}$ (a.s.l.)) $\sim 80 \mathrm{~km}$

\footnotetext{
'Also at UFR de Mécanique, Université Joseph Fourier de Grenoble, Domaine Universitaire, Grenoble, France.
}

Copyright 1995 by the American Geophysical Union.

Paper number 95JD00989.

0148-0227/95/95JD-00989\$05.00 from Camp Century. In addition, they also obtained the first estimate of natural $\mathrm{Pb}$ concentrations in Greenland Holocene ice by analyzing a single block of blue ice dated $\sim 2800$ years B.P. collected at Camp Tuto $\left(76^{\circ} 25^{\prime} \mathrm{N}, 68^{\circ} 20^{\prime} \mathrm{W}\right)$. They found that the $\mathrm{Pb}$ concentration was exceedingly low, $\sim 0.8 \mathrm{pg} / \mathrm{g}, 2800$ years B.P., before man started to impact significantly on the atmosphere, and that this natural $\mathrm{Pb}$ could be explained simply by $\mathrm{a}$ soil and rock dust contribution. In the $1750 \mathrm{~s}, \mathrm{~Pb}$ concentration was found to be $-10 \mathrm{pg} / \mathrm{g}$, that is one order of magnitude higher than the value for 2800 years B.P.: it clearly evidenced for the first time that the Arctic atmosphere was already strongly contaminated in $\mathrm{Pb}$ before the onset of the Industrial Revolution. From the 1750 s to 1965 , a further continuous $\sim 20$ fold increase was observed, the increase being especially rapid after the $1930 \mathrm{~s}$ as a response to the introduction and subsequent massive use of $\mathrm{Pb}$ alkyl additives [Nriagu, 1990] in automobile gasoline. On the whole, $\mathrm{Pb}$ concentrations appeared to have massively increased by about 200 fold from several thousand years ago to the 1960s in Greenland snow and ice, providing the first clear evidence of massive large-scale pollution of the atmosphere of the northern hemisphere for this toxic metal. And it is at least partially because of this landmark work that the United States and various other countries severely limited their use of $\mathrm{Pb}$ alkyl additives in gasoline from the early 1970s.

During the following two and half decades, various other investigators tried to emulate this pioneering work, not only for $\mathrm{Pb}$ but also for several other heavy metals such as $\mathrm{Cd}, \mathrm{Hg}, \mathrm{Cu}$, 
and Zn [e.g. Weiss et al., 1971 a,b, 1975; Carr and Wilkniss, 1973; Cragin et al., 1975; Herron et al., 1977; Appelquist et $a l ., 1978$ ]. None of them succeeded in producing reliable time series for the past few centuries, mainly because they were unable to fully control contamination problems during field sampling, laboratory analysis or both.

The only reliable data which became available during these 25 years were either for ancient ice or for recent (post-1965) snow. C. Patterson and his coworkers were able to successfully meet the very difficult requirements of decontaminating deep Greenland ice cores for heavy metals analysis $[\mathrm{Ng}$ and Patterson, 1981]. It allowed them to analyze, for $\mathrm{Pb}$, a few sections of the Camp Century $1387-m$ ice core whose age ranged from 2700 to 5500 years B.P., and to confirm that the natural $\mathrm{Pb}$ concentration in Greenland Holocene ice was really at the picogram-per-gram level as previously claimed by Murozumi et al. [1969] from the analysis of their single block of blue ice. For recent snow, various reliable data were published from the analysis of shallow samples collected in southern or central Greenland either from the walls of hand dug pits [Wolff and Peel, 1988; Boyle et al., 1994; Savarino et al., 1994; Candelone et al., 1995] or using specially designed acid cleaned all-plastic augers [Boutron et al., 1991]. These last data show that $\mathrm{Pb}$ concentrations have decreased by a factor of 7.5 since the mid-1960s in central Greenland as a consequence of the reduction in the use of $\mathrm{Pb}$ alkyl additives especially in the United States. During the same period, $\mathrm{Cd}$ and $\mathrm{Zn}$ concentrations were found to have decreased by a factor of $\mathbf{2 . 5}$ in response to the increasing efforts made in various countries of the northern hemisphere to reduce the emissions of these metals to the atmosphere from the combustion of fossil fuels, metal processing activities, and refuse incineration. They also revealed that there are pronounced intra annual (seasonal) variations in heavy metals concentrations in recent Greenland snow.

Confronted with the lack of confirmation of the $\mathrm{Pb}$ time series of Murozumi et al. [1969] and with the lack of time series for other metals for the past few centuries, we decided to collect and analyze for $\mathrm{Pb}, \mathrm{Zn}, \mathrm{Cd}$, and $\mathrm{Cu}$ new samples covering the post-Industrial Revolution period, that is the past $\sim 220$ years, using improved ultraclean procedures. The results are interpreted and discussed in the light of available data on anthropogenic emissions of these metals to the atmosphere.

\section{Experiment}

\subsection{Field Sampling}

The samples were collected in July 1989 at Summit $\left(72^{\circ} 34^{\prime} \mathrm{N}, 37^{\circ} 37^{\prime} \mathrm{N}\right.$, elevation $3238 \mathrm{~m}$ (a.s.l.), mean annual temperature $-32^{\circ} \mathrm{C}$, mean annual snow accumulation rate $23 \mathrm{~g}$ $\left.\mathrm{cm}^{-2} \mathrm{yr}^{-1}\right)$ as part of the European "Eurocore" program. They consisted of a snow/ice core $9.8 \mathrm{~cm}$ in diameter and $70.3 \mathrm{~m}$ deep, which was electromechanically drilled only for our heavy metals measurements. To minimize local contamination problems, the exact sampling site was selected about $500 \mathrm{~m}$ from the Eurocore camp. In order to minimize contamination brought to the outside of the core during drilling operations, we used a stainless steel drill [Gillet et al., 1984] which was coated with polytetrafluoroethylene (PTFE).

Core handling was kept to a strict minimum. Each core section was handled by operators wearing full clean room clothing and shoulder length polyethylene gloves, using specially designed acid cleaned low density polyethylene (LDPE) pistons (to push the core section out of the drill if necessary), brushes (to remove the cutting chips from the outside of the core), gutters (to keep the core sections before packing), and saws.

Each core section (about $1 \mathrm{~m}$ long) was packed inside double-sealed LDPE bags and transported frozen to Grenoble, France.

\subsection{Decontamination of the Core Sections}

Despite the great precautions which were taken in the field to minimize contamination brought to the outside of the core, significant contamination was found to be present on the outside of the core sections. This contamination was especially pronounced for $\mathrm{Zn}$ : for this metal, measured concentrations in the first centimeter or so from the outside ranged indeed from about 1000 to $5000 \mathrm{pg} / \mathrm{g}$, that is, concentrations higher by up to 2 orders of magnitude than the original $\mathrm{Zn}$ concentration in the snow. This $\mathrm{Zn}$ contamination was thought to originate at least partially from the galvanized steel cable of the electromechanical drill.

Each of the analyzed core sections was therefore mechanically decontaminated before analysis, using ultraclean procedures, in order to remove the contaminated outside veneer layers and get the uncontaminated innermost part of the core. The decontamination took place inside a laminar flow clean bench located in a $-15^{\circ} \mathrm{C}$ cold room.

For low and medium-density snow sections (depth down to $\sim 20 \mathrm{~m}$ ) the decontamination procedure was similar to that described by Boutron et al. [1991] and Görlach and Boutron [1992]. It involved breaking the core sections with a sharpedged LDPE splitting wedge in order to obtain 20 or $15 \mathrm{~cm}$ long sections with fresh untouched surfaces at both extremities, then extracting the central part (diameter: $4 \mathrm{~cm}$ ) of these 20 or $15 \mathrm{~cm}$ sections by hammering a home made cylindrical LDPE beaker into the center of one of the untouched surfaces parallel to the core axis. Additional subsamples were also obtained at increasing distances from the axis using smaller diameter LDPE beakers.

Below $\sim 20 \mathrm{~m}$, with the higher density of the snow, it was no longer possible to use this procedure, and a new improved procedure, described in detail by Candelone et al. [1994], was employed. It involved supporting the core section horizontally in a LDPE home made lathe [Candelone et al., 1994] then chiselling successive veneers of snow (or ice for the deepest sections) in progression from the outside towards the center, using the same stainless steel chisels used by $C$. Patterson and his coworkers in their Antarctic ice cores work [Boutron and Patterson, 1986]. The two extremities of the inner core (diameter: $4 \mathrm{~cm}$ ), obtained when the procedure was completed, were then broken using chisels while firmly held with all LDPE homemade tongs. A distinct advantage of this improved procedure is that it is possible to handle sections of variable length and obtain inner cores which integrate a given time period, for instance an exact full year.

The procedural blank for the chiselling procedure was accurately determined by processing an artificial ice core [Candelone et al., 1994] made by freezing ultrapure water [Boutron, 1990] whose heavy metals content was known beforehand. It ranged from $0.015 \mathrm{pg} / \mathrm{g}$ for $\mathrm{Cd}$ up to $0.25 \mathrm{pg} / \mathrm{g}$ 
for $\mathrm{Cu}$ [Candelone et al., 1994], that is contributions which are extremely small compared to heavy metals concentrations in post-Industrial Revolution Greenland snow and ice.

\subsection{Checking the Efficiency of the Decontami- nation Procedure}

As previously emphasised by various authors $[\mathrm{Ng}$ and Patterson, 1981; Boutron and Patterson, 1986; Peel, 1989; Wolff, 1990; Boutron et al., 1994, 1995], it is essential to determine changes in the concentrations of each heavy metal from the outside to the inside of each analyzed core section to make certain that concentrations measured in the central part, obtained after the decontamination is completed, do represent the original concentration in the snow or ice. If a clear plateau of concentration is obtained in the central part, it indicates that external contamination has not penetrated to this central part: the plateau concentration will then represent the original concentration in the snow or ice, providing an appropriate blank correction is made for the whole analytical procedure. If, on the other hand, a continuous decrease of concentration is observed to the most central parts, this indicates that external contamination has probably reached the center of the core: the corresponding concentration value then gives only an upper limit of the original concentration in the snow or ice.

Outside-inside concentration profiles have been obtained for all four heavy metals for each of the investigated core sections. In most cases, good plateaus of concentrations were observed, as illustrated in Figure 1 for $\mathrm{Cu}$ and $\mathrm{Zn}$ in the 61.56-61.85-m section. A continuous decrease of concentrations from the outside to the center was observed in a few cases only, as shown in Figure 2 for $\mathrm{Cu}$ in the 69.93-70.17-m section and $\mathrm{Zn}$ in the 51.76-52.23-m section.

\subsection{Analytical Procedures}

Each veneer layer and inner core was analyzed separately using ultraclean procedures [Boutron, 1990]. $\mathrm{Pb}, \mathrm{Cd}$, and $\mathrm{Cu}$

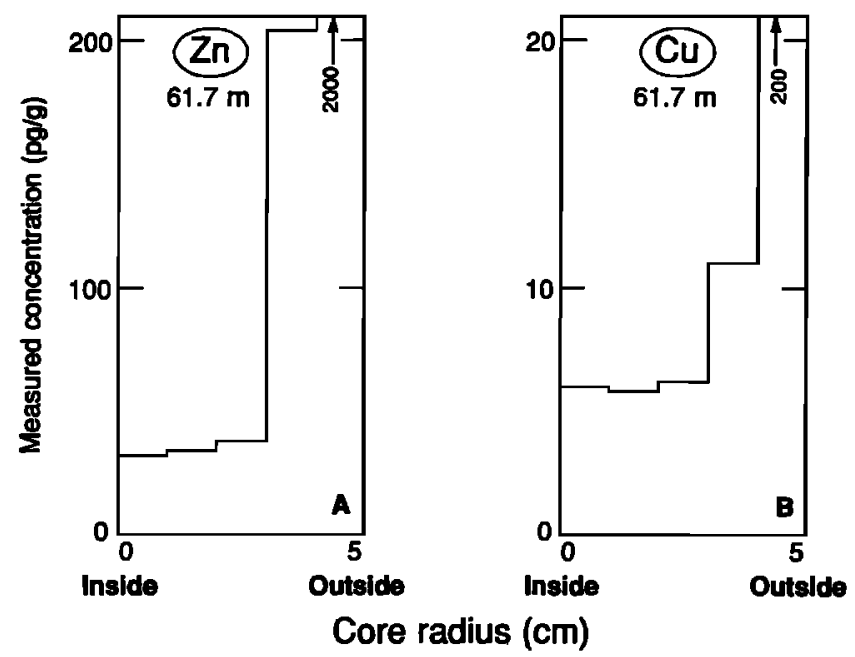

Figure 1. Measured $\mathrm{Zn}$ and $\mathrm{Cu}$ concentrations as a function of radius in the $61.56-61.85$ section of the $70.3 \mathrm{~m}$ snow/ice core electromechanically drilled at Summit, central Greenland. Good plateaus of concentrations are obtained in the central part of the core section.

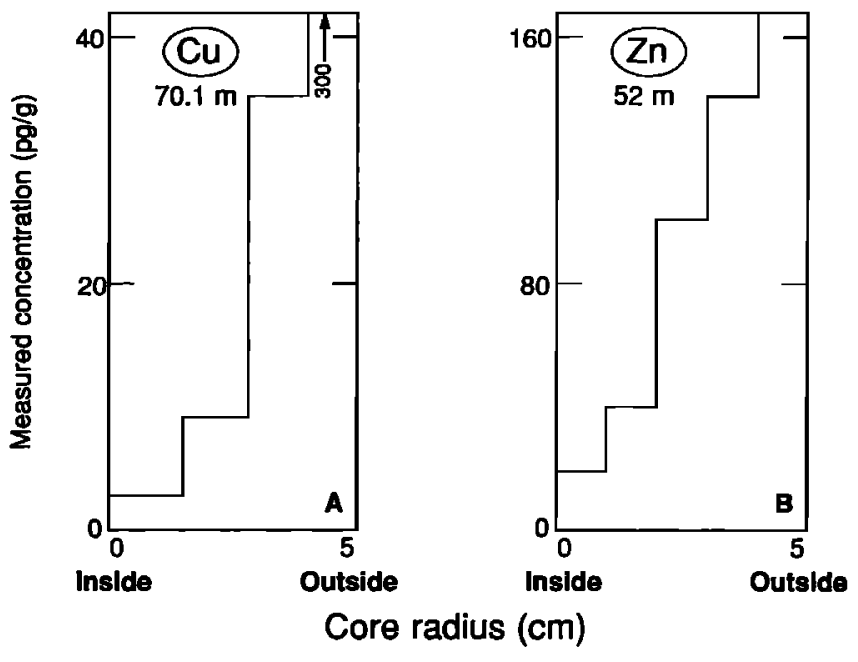

Figure 2. Measured heavy metals concentrations as a function of radius in two sections of the 70.3-m snow/ice core electromechanically drilled at Summit, central Greenland. (A) $\mathrm{Cu}$ in the 69.93-70.17-m section (year 1773); (B) $\mathrm{Zn}$ in the 51.76-52.23-m section (years 1841-1842). No satisfying plateau of concentrations is obtained in the central part of the core section for these two cases.

were determined by graphite furnace atomic absorption spectrometry (GFAAS) after preconcentration $(\sim x 50)$ by non boiling evaporation [Görlach and Boutron, 1990]. $\mathrm{Zn}, \mathrm{Al}$, and $\mathrm{Na}$ were measured by GFAAS without preconcentration. The GFAAS measurements were performed with a Perkin Elmer 2380 spectrometer and HGA 500 graphite furnace, using electrodeless discharge lamps for $\mathrm{Pb}, \mathrm{Cd}$, and $\mathrm{Zn}$. Pyrolitically coated graphite tubes from Applied Optics were used. The precision of the data is estimated to be $\pm 10 \%$.

Various $0.1 \% \mathrm{HNO}_{3}$ (ultrapure twice-distilled $\mathrm{HNO}_{3}$ from US National Institute of Standards and Technology [Paulsen et al. 1988]) aliquots were also taken for subsequent determination of $\mathrm{Pb}$ by isotope dilution mass spectrometry (IDMS) [Rosman et al., 1993, 1994], $\mathrm{Pb}$ isotopes by thermal ionization mass spectrometry (TIMS) [Rosman et al., 1993, 1994], ethyl and methyl $\mathrm{Pb}$ compounds by capillary gas chromatography with microwave-induced plasma atomic emission spectrometry (CGC-MIP-AES) [Lobinski et al., 1993, 1994], and $\mathrm{Hg}$ by cold vapor atomic fluorescence spectrometry (CVAFS) [Vandal et al., 1993].

Comparative determination of $\mathrm{Pb}$ by GFAAS after preconcentration and IDMS indicated that the IDMS values were systematically slightly lower, by $\sim 20 \%$, than the GFAAS values when these last values were corrected using the slope $(0.82)$ of the calibration line of the preconcentration procedure given by Görlach and Boutron [1990]. They were, on the other hand, in excellent agreement if this correction was not made. Taking into account the fact that IDMS is essentially an absolute technique, we have therefore decided to no longer apply a correction for the preconcentration procedure not only for $\mathrm{Pb}$, but also for $\mathrm{Cd}, \mathrm{Cu}$, and $\mathrm{Zn}$ (for these last metals, this results in decreasing the values by $24 \%, 11 \%$, and $15 \%$, respectively). It must however be emphasised that these relatively small differences do not significantly influence the geochemical interpretation of the snow and ice data. 


\subsection{Dating of the Samples}

The dating of the core was based on detailed continuous oxygen isotopes data obtained in a nearby parallel core [H. Clausen, personal communication, 1993). It indicates that the bottom of the core $(70.3 \mathrm{~m})$ corresponds to the year 1772 , that is, slightly before the beginning of the first Industrial Revolution. The whole core then covers continuously a 217year time period. The precision of the dating is estimated to be about \pm 2 years at the bottom of the core.

\section{Results and Discussion}

\subsection{Presentation of the Data}

Since comprehensive heavy metals data had already been obtained for the 1967-1989 period from the analysis of a 10.7m snow core drilled at a nearby location [Boutron et al., 1991], we mainly analyzed the part of the 70.3-m core corresponding to the pre-1966 period. Special attention was moreover given to the 1945-1966 period (depth interval 20-11 m), which was expected to correspond to a rapid increase of $\mathrm{Pb}$ concentrations in response to the massive use of $\mathrm{Pb}$ alkyl additives in gasoline after World War II.

Table 1 displays $\mathrm{Pb}, \mathrm{Cd}, \mathrm{Zn}$, and $\mathrm{Cu}$ concentrations measured in the central part of each of the 26 investigated core sections. For the core sections which were decontaminated using the stainless steel chisels, (see section 2.2), that is, the sections whose depth was greater than $20 \mathrm{~m}$, the chiselling procedure was conducted so that the length of the inner core obtained after the decontamination was completed integrated exactly 1 or 2 years of snow or ice accumulation at the corresponding depth (estimated from the detailed oxygen isotopes profiles). For these sections, each data point given in Table 1 then exactly corresponds to a 1 or 2 year time interval. It is then not influenced by intra annual (seasonal) variations of the concentrations [Wolff and Peel, 1988; Boyle et al., 1994; Savarino et al., 1994; Candelone et al., 1995].

For the core sections which were decontaminated using the earlier procedure (see section 2.2) of Boutron et al. [1991] and Görlach and Boutron [1992], that is, the sections whose depth was less than $20 \mathrm{~m}$, the situation is more complicated. The depth interval associated with each data point often does not

Table 1. Summit, Central Greenland: Heavy Metals Concentrations Measured in the Central Part of Various Sections of a 70.3-m Snow/Ice Core

\begin{tabular}{|c|c|c|c|c|c|}
\hline \multirow{2}{*}{$\begin{array}{c}\text { Depth Interval* } \\
\mathbf{m}\end{array}$} & \multirow{2}{*}{$\begin{array}{c}\text { Aget, Calendar } \\
\text { Year }\end{array}$} & \multicolumn{4}{|c|}{ Measured Concentration, pg/g } \\
\hline & & $\mathrm{Pb}$ & $\mathbf{Z n}$ & $\mathrm{Cd}$ & $\mathrm{Cu}$ \\
\hline 7.48- 7.93 & 1974.5 & 84 & 60 & 1.7 & 7.6 \\
\hline $9.79-10.11$ & 1969.6 & 109 & 46 & 1.5 & 3.2 \\
\hline $10.92-11.25$ & 1965.4 & 99 & 60 & 1.3 & 8.3 \\
\hline $11.44-11.77$ & 1964.1 & 88 & 129 & 1.5 & 9 \\
\hline $11.96-12.25$ & 1963 & 90 & 75 & 1.3 & 7.9 \\
\hline $12.54-12.86$ & 1961.6 & 65 & 72 & 0.85 & 13 \\
\hline $12.98-13.27$ & 1960.4 & 60 & 49 & 0.78 & 4 \\
\hline $13.37-13.67$ & 1959.2 & 126 & 155 & 2.2 & 15 \\
\hline $13.74-14.17$ & 1958.2 & 59 & 54 & 0.82 & 3.2 \\
\hline $14.38-14.69$ & 1956.9 & 90 & 74 & 1.2 & 6.4 \\
\hline $15.17-15.62$ & 1954.7 & 67 & 75 & 1.2 & 7.5 \\
\hline $15.80-16.17$ & 1953.2 & 81 & 134 & 3.3 & 17 \\
\hline $16.69-16.97$ & 1951.2 & 67 & 67 & 1.4 & 7.3 \\
\hline $17.30-17.58$ & 1949.7 & 88 & 71 & 2.9 & 7.1 \\
\hline $18.08-18.54$ & 1948 & 49 & 79 & 2.1 & 6.8 \\
\hline $18.66-19.11$ & 1946.6 & 31 & 42 & 1.2 & 4.9 \\
\hline $21.10-21.45$ & 1940 & 41 & 75 & 1.1 & 8.6 \\
\hline 23.6424 .08 & 1933 & 18 & 90 & 1.1 & 9.3 \\
\hline $25.48-25.92$ & 1928 & 45 & 65 & 2.0 & 6.9 \\
\hline $29.77-30.13$ & 1915 & 34 & 34 & 1.2 & 5.2 \\
\hline $37.27-37.60$ & 1891 & 63 & 30 & 1.1 & 4.9 \\
\hline $43.90-44.45$ & $1869-1870$ & 18 & 44 & 0.68 & 2.7 \\
\hline $51.76-52.23$ & $1841-1842$ & 17 & 22 & 0.15 & 2.4 \\
\hline $58.20-58.50$ & 1817 & 4.4 & 29 & 0.23 & 3.5 \\
\hline $61.56-61.85$ & 1805 & 12 & 20 & 0.21 & 6.1 \\
\hline $69.93-70.17$ & 1773 & 7.6 & 16 & 0.27 & 2.8 \\
\hline
\end{tabular}

*Surface: July 1989.

†Estimated age for the middle of the corresponding core section. 
correspond exactly to 1 year of snow accumulation, since it was determined by the cumulative length of the LDPE beakers hammered into the core. It can be seen in Table 1 that the corresponding depth interval was often $\sim 30$ to $35 \mathrm{~cm}$, which represents slightly less than 1 year of snow accumulation at these depths (at $15 \mathrm{~m}$, for instance, 1 year of snow accumulation is approximately equal to $40 \mathrm{~cm}$ ). Because these samples do not represent exactly 1 year of accumulation, the corresponding data points are probably influenced by seasonal variations in concentrations: this will result in a larger scatter in the data points, as it will be seen in the time series discussed in sections 3.2 and 3.3

\subsection{Changes in $\mathrm{Zn}, \mathrm{Cd}$, and $\mathrm{Cu}$ Concentrations From 1773 to 1992}

Changes in the concentrations of these three metals from 1773 to 1992 are shown in Figure 3 as documented by combining the data obtained in this work from the analysis of the 70.3-m core with the data given by Boutron et al. [1991] for the 1967-1989 period (averaged so that each data point corresponds approximately to 1 year of snow accumulation)

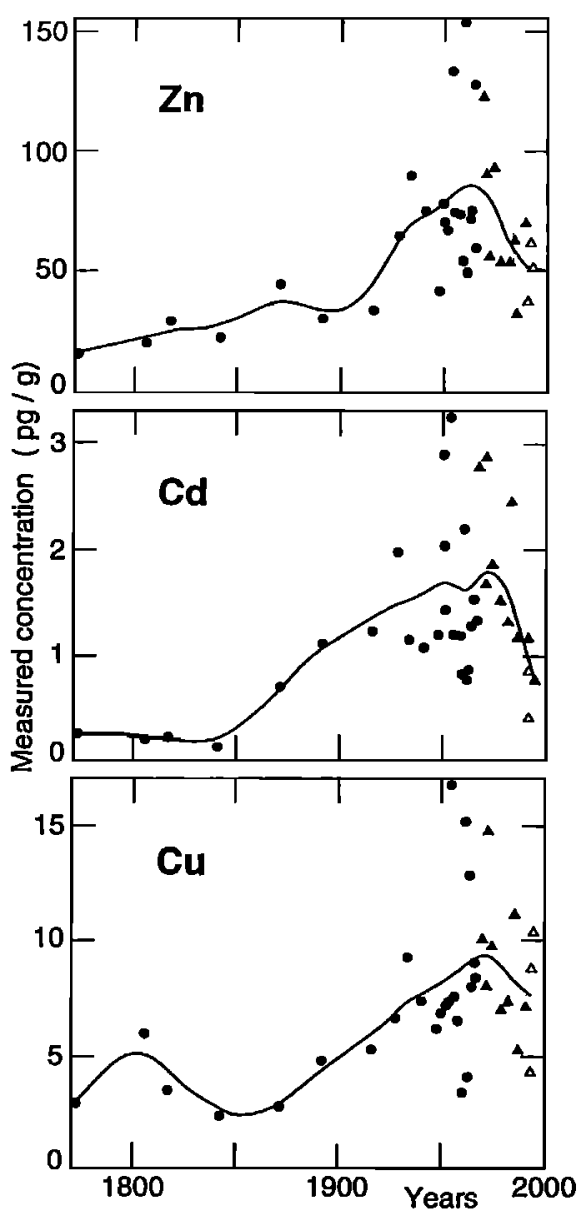

Figure 3. Changes in $\mathrm{Zn}, \mathrm{Cd}$, and $\mathrm{Cu}$ concentrations in snow/ice deposited at Summit, central Greenland, from 1773 to 1992. Solid circles: this work (70.3-m core); solid triangles: averaged values from Boutron et al. [1991] (10.7-m core); open triangles: mean yearly values for 1990, 1991, and 1992 from Candelone et al. [1995] (1.6-m snow pit). The general time trends are shown with spline-smoothed curves. and with the mean yearly values for the years 1990, 1991, and 1992 given by Candelone et al. [1995]. The data of Boutron et al. [1991] were obtained from the analysis of a 10.7-m snow core drilled using a specially designed all-plastic acid cleaned mechanical auger. The data of Candelone et al. [1995] were obtained from the analysis of a continuous sequence of 30 samples collected by pushing ultraclean wide mouth LDPE bottles into the walls of a 1.6-m deep hand-dug snow pit. This is the first reliable time series ever published for these three metals, since previously published data [Weiss et al., 1975; Herron et al., 1977] were plagued by major contamination problems.

A common feature of the three time series shown in Figure 3 is the existence of a clear increasing trend until the 1960 s and 1970s, followed by a significant decreasing trend. But a detailed examination of the profiles reveals pronounced differences for the three metals.

First of all, the timing of the observed increase is not the same. For $\mathrm{Zn}$, our data indicate that the increase started as early as the 1770 s. It was, however, fairly slow until the 1900 s, then became more rapid during the first half of the 20th century. For $\mathrm{Cd}$ and $\mathrm{Cu}$, on the other hand, the increase did not start until the 1850 s (the maximum shown by the spline function around the 1800 s for $\mathrm{Cu}$ is probably not significant since it is due only to a single data point). Its rate was, moreover, fairly stable during the following 1 century or so.

Another difference is with the amplitude of the observed increases. Cd shows the greatest increase $(\sim \times 8)$, followed by $\mathrm{Zn}(\sim \mathrm{X})$ and $\mathrm{Cu}(\sim \mathrm{x} 4)$.

Also, the time when the maximum is observed is not the same. The spline-smoothed curves shown in Figure 3 suggest that the maximum was reached earlier for $\mathrm{Zn}$ (around 1961) than for $\mathrm{Cd}$ and $\mathrm{Cu}$ (around $~ 1972$ and 1969, respectively).

Finally, the amplitude of the recent decrease differs from one metal to another. $\mathrm{Cd}$ is found to have decreased by a factor of $\sim 2.3$ during the past 2 decades down to 1992 values, which are similar to those around the $1870 \mathrm{~s}$. For $\mathrm{Zn}$, the decrease appears to be smaller (factor of $\sim 1.7$ ), with the 1992 values similar to those in the $1920 \mathrm{~s}$. The decrease for $\mathrm{Cu}$ appears to be hardly significant (factor of $\sim 1.2$ ), with the 1992 values close to those observed in the 1930 s.

These changes cannot be linked with changes in emissions from natural sources to the atmosphere, such as rock and soil dust, sea salt spray, and volcanoes [Nriagu, 1989]. The corresponding emissions have indeed not significantly changed since the 18th century, as evidenced, for instance, for the rock and soil dust and sea-salt spray contributions by the fact that no time trend is observed since the 1770 s for $\mathrm{Al}$ and sea salt $\mathrm{Na}$ (Table 2). They are then, without doubt, the result of major changes in the large scale anthropogenic emissions of these metals to the atmosphere of the northern hemisphere.

There is a wealth of data available on the world production of $\mathrm{Cd}, \mathrm{Cu}$, and $\mathrm{Zn}$ during the past century or so, for instance, in extremely detailed publications of the United Kingdom government [Imperial Mineral Resources Bureau, 1913-1920; Imperial Institute, 1920-1944; Colonial Geological Survey 1945-1951; National Environmental Research Council, 19521970; National Environmental Research Council, 1970-1990] and the U.S. Bureau of Mines [1930-1990] or in specialized books devoted to given metals [e.g. Nriagu, 1978, 1979a, b, c]. Although the past trends in metals production have often been used as surrogates for trends in past metals emissions to the 
Table 2. Measured $\mathrm{Al}$ and Sea-Salt $\mathrm{Na}\left(\mathrm{Na}_{\mathrm{ss}}\right)$ Concentrations in Typical Samples Whose Age Ranges from 1773 to 1992

Measured Concentration, ng/g

\begin{tabular}{ccc}
\cline { 2 - 3 } Year & $\mathrm{Al}$ & $\mathrm{Na}_{\text {ss }}$ \\
\hline 1773 & 4.3 & 2.4 \\
1817 & 5.6 & 4.4 \\
1870 & 7.6 & 4.1 \\
1915 & 5.0 & 2.3 \\
1940 & 8.6 & 0.7 \\
1968 & 3.7 & 0.9 \\
$1992^{*}$ & 5.6 & 3.2 \\
& & \\
\hline
\end{tabular}

Concentrations of $\mathrm{Na}_{\text {ss }}$ were calculated by correcting measured $\mathrm{Na}$ concentrations for the crustal component evaluated from $\mathrm{Al}$ concentrations using the $\mathrm{Na} / \mathrm{Al}$ abundance ratio in the mean crustal material [Taylor and McLennan, 1985].

* From Candelone et al. [1995].

atmosphere [e.g., Wolff and Suttie, 1994], they however do not satisfyingly represent these trends.

On the other hand, the available data on world emissions (which originate mainly from non- ferrous metals production and also from coal combustion, steel and iron manufacturing, and refuse incineration) are much sparser. Even for recent years the best available estimates [Nriagu and Pacyna, 1988; Pacyna, 1994] remain rather uncertain. For instance, the ranges for the estimates of worldwide emissions for $\mathrm{Zn}, \mathrm{Cd}$, and $\mathrm{Cu}$ for the year 1983, given by Nriagu and Pacyna [1988], are (in metric tons per year) $70,000-194,000,3,100-12,000$, and 19,900 50,900 respectively, that is, uncertainties by up to a factor of 4. The few data on historical changes in these emission fluxes [e.g., Nriagu 1979d] are even sparser.

Table 3 compares the mean ratios of total emissions (anthropogenic plus natural, 1983 values)/natural emissions given by Nriagu [1989] with the enhancement factors which we observe in Summit snow and ice from 1773 to 1983 (that is, not the enhancement factors discussed above, which were for the time period from 1773 to the time when the maximum is reached). It must be noted that this comparison relies upon the fact that concentrations measured in the ice in 1773 are entirely natural, which is indeed the case, as will be discussed in section 3.4. It can be seen in Table 3 that the increase factors are in remarkable agreement with the mean ratios, which shows that the historical changes in $\mathrm{Zn}, \mathrm{Cd}$, and $\mathrm{Cu}$ deposition in Greenland are consistent with the estimates of emissions.

Finally, the decreasing trend which we observe from the early 1960 s for $\mathrm{Zn}$ and from the early 1970 s for $\mathrm{Cd}$ and possibly $\mathrm{Cu}$ appears to be consistent with the very significant reported decrease in the emissions in the northern hemisphere as a consequence of the abatement measures which were taken in various countries of the northern hemisphere during the past decades [Pacyna, 1989, 1991; Pacyna et al., 1993; Thomas and Spiro, 1994]. For instance, Pacyna [1991] estimated that emissions of $\mathrm{Cd}$ and $\mathrm{Zn}$ from Europe, which are likely to be a significant contribution to $\mathrm{Cd}$ and $\mathrm{Zn}$ deposited in Greenland, peaked in the 1970s, and that the 1980 emissions were about three times lower than the pre-mid-1970s ones. His estimates were obtained from a comprehensive review of changes in emission factors for these two metals in Europe from the 1950s up to $\mathbf{1 9 8 5}$ for major source categories such as non ferrous metal production and combustion of fuels [Pacyna, 1991]. In addition to the impact of these abatement measures it is also likely that a significant reduction of the emissions also resulted from the very strong economic recession which has affected the states of the former Soviet Union during the past few years. These reductions are thought to have been especially important for the highly polluting non ferrous metal production activities in the Russian Arctic, for instance, in the Kola Peninsula [Jaffe et al., 1995].

\subsection{Changes in Pb Concentrations From 1773 to 1992}

Changes in $\mathrm{Pb}$ concentrations from 1773 to 1992 are shown in Figure 4. This time series is the first verification and extension of the pioneering data published 25 years ago by Murozumi et al. [1969] for the years 1753-1965, which are also shown in Figure 4.

For the time period covered by both time series, the general trends obtained from both sets of data are similar: our data confirm the very large increase in concentration from the middle of the 18th century to the 1960s seen in the earlier work. However, our data appear to be systematically lower than those of Murozumi et al. [1969]. A possible explanation for this discrepancy is that it would be linked with the different geographical characteristics of the sampling sites. The samples of Murozumi et al. [1969] were indeed collected at a much lower altitude than our samples (1800 instead of $3238 \mathrm{~m}$ a.s.l.): the high altitude-free troposphere of Summit is likely to be less contaminated. Moreover, the sampling sites of Murozumi et al. [1969] were located in north west Greenland, that is, an area which is more affected by the Arctic haze phenomenon [Barrie, 1986] than central Greenland. An alternative explanation could, however, be that the data of Murozumi et al. [1969], although of outstanding quality at the time when they were obtained, suffered slight but, however, significant contamination. They were indeed not meeting all

Table 3. Comparison of $\mathrm{Zn}, \mathrm{Cd}$, and $\mathrm{Cu}$ Levels

\begin{tabular}{llll} 
& $\mathrm{Zn}$ & $\mathrm{Cd}$ & $\mathrm{Cu}$ \\
\hline $\begin{array}{l}\text { Total/Natural world } \\
\text { emissions }\end{array}$ & 3.9 & 6.9 & 2.3 \\
$\begin{array}{l}\text { Enhancement factor in } \\
\text { Greenland snow and ice } \\
\text { from } 1773 \text { to } 1983\end{array}$ & 3.4 & 6.3 & 2.6 \\
\hline
\end{tabular}

Comparison of the Mean Ratio of Total World Emissions (Anthropogenic Plus Natural, 1983 values) / Natural World Emissions With the Enhancement Factor in Summit, Central Greenland, Snow and Ice from 1773 to 1983.

"Nriagu and Pacyna [1988]. 


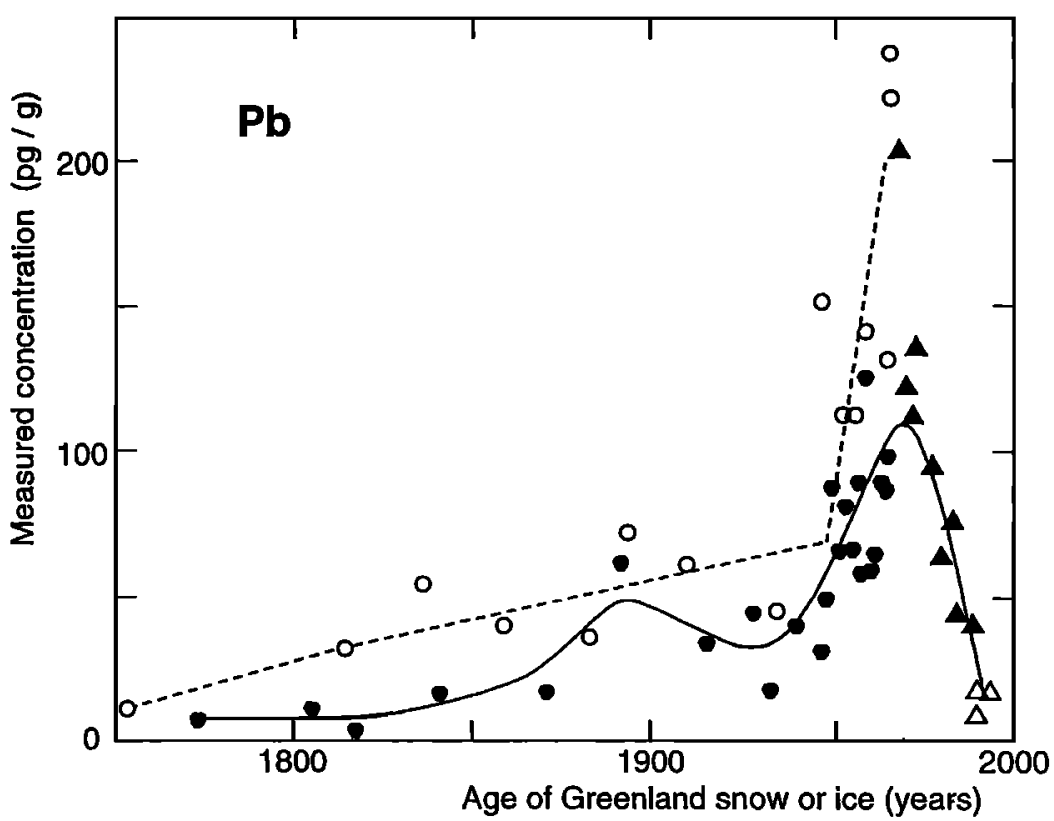

Figure 4. Changes in $\mathrm{Pb}$ concentrations in snow/ice deposited at Summit, central Greenland, from 1773 to 1992. Solid circles: this work (70.3-m core); solid triangles: averaged values from Boutron et al. [1991] (10.7-m core); open triangles: mean yearly values for 1990, 1991 and 1992 from Candelone et al. [1995] (1.6m snow pit). The general time trend is shown with a spline-smoothed curve. Also shown, with open circles, are the original data of Murozumi et al. [1969] for the Camp Century area in north west Greenland (the dotted line shown on the figure is the original one given by Murozumi et al. [1969]).

standards of quality by which heavy metals work is now judged, especially regarding the necessity of taking outsideinside profiles across the samples. Such profiles, which were first proposed by $\mathrm{Ng}$ and Patterson [1981], were not studied for the snow blocks analyzed by Murozumi et al. [1969].

A more detailed examination of the data in Figure 4 indicates that there are different growth regimes between 1773 and 1992. From 1773 to the -1890 s, first, a rather slow increase ( $\sim 6.3$ fold in $\sim 130$ years) is observed. It is attributed to the progressive increase in $\mathrm{Pb}$ emissions to the atmosphere of the northern hemisphere, linked with the anthropogenic sources which were dominant at that time when $\mathrm{Pb}$ alkyl additives in gasoline were still not used. The most important of these sources were non ferrous metals production $(\mathrm{Pb}, \mathrm{Cu}-\mathrm{Ni}$, and $\mathrm{Zn}-\mathrm{Cd}$ ), iron and steel manufacturing, and coal and wood combustion [Nriagu, 1978, 1979d; Patterson, 1980; Nriagu and Pacyna, 1988; Wolff and Suttie, 1994].

The spline-smoothed curve shown in Figure 4 suggests that this -130 year period was followed by a few decades around the 1920s-1930s during which $\mathrm{Pb}$ concentrations seem to have slightly decreased. From our data points, it is difficult to determine whether this decrease is significant or not: more data points would obviously be needed, especially for the 1880 s1920 s. It is however interesting to see that such a decline around the $1920 \mathrm{~s}-1930$ s was also suggested by the data of Murozumi et al. [1969] (see Figure 4). If real, it could indicate that $\mathrm{Pb}$ emissions to the atmosphere declined during the big economic recession, as already documented for other pollutants such as $\mathrm{SO}_{2}$ [e.g. Möller, 1984].

Starting from the $-1930 \mathrm{~s}$, a large and rapid increase is then observed until $\sim 1970(\sim 3.4$ fold in $\sim 40$ years $)$. Although the contribution from other sources such as non ferrous metals production certainly remained very significant during that period, and probably played a role in the observed increase, there is little doubt that this rapid increase was largely caused by the introduction (in 1923) and massive increase in the use of $\mathrm{Pb}$ alkyl additives in automobile and aviation gasoline [Nriagu, 1990]. The consumption of additives massively increased from 1923 to 1970 , reaching a peak value of $400,000 \mathrm{t} / \mathrm{yr}$ in the early $1970 \mathrm{~s}$. It is estimated that $-70 \%$ of the lead content in the additives was emitted to the atmosphere via the exhaust pipes of the engines. The largest part of these emissions occurred in the northern hemisphere, where there are the most cars (95\% in 1948; 93\% now [Wolff and Suttie 1994].

Further unambiguous evidence of the key role played by $\mathbf{P b}$ alkyl additives in the rapid increase of concentrations from the 1930s to $\sim 1970$ was recently obtained thanks to the direct measurement of organo- $\mathrm{Pb}$ compounds $\left(\mathrm{Et}_{3} \mathrm{~Pb}^{+}\right.$and $\left.\mathrm{Et}_{2} \mathrm{~Pb}^{++}\right)$ in aliquots of part of the post-1923 samples analyzed in this work [Lobinski et al., 1994]. These compounds, which have no natural origin and are unique tracers of gasoline-related pollution [Granjean, 1983; Van Cleuvenbergen and Adams, 1990] were indeed found to be present above detection limit (10 fg/g Lobinski et al., 1993]) in our samples from the 1930s, with a marked increasing trend to the 1970s. Additional evidence was also provided by the determination of the isotopic pattern of $\mathrm{Pb}\left(\mathrm{Pb}^{204}, \mathrm{~Pb}^{206}, \mathrm{~Pb}^{207}\right.$. and $\left.\mathrm{Pb}^{208}\right)$ in other aliquots [Rosman et al., 1994, 1995].

After this final increase a clear maximum of $\mathrm{Pb}$ concentrations is observed in -1970 , Figure 4, followed by a pronounced decrease from -1970 to $1992(-6.5$ fold in 2 decades) which brings the 1992 values back down to the concentrations observed in the mid-19th century (Figure 4). Part of this decrease is probably due to the reduction in emissions from non ferrous metal production and steel and iron manufacturing, resulting from abatement measures 

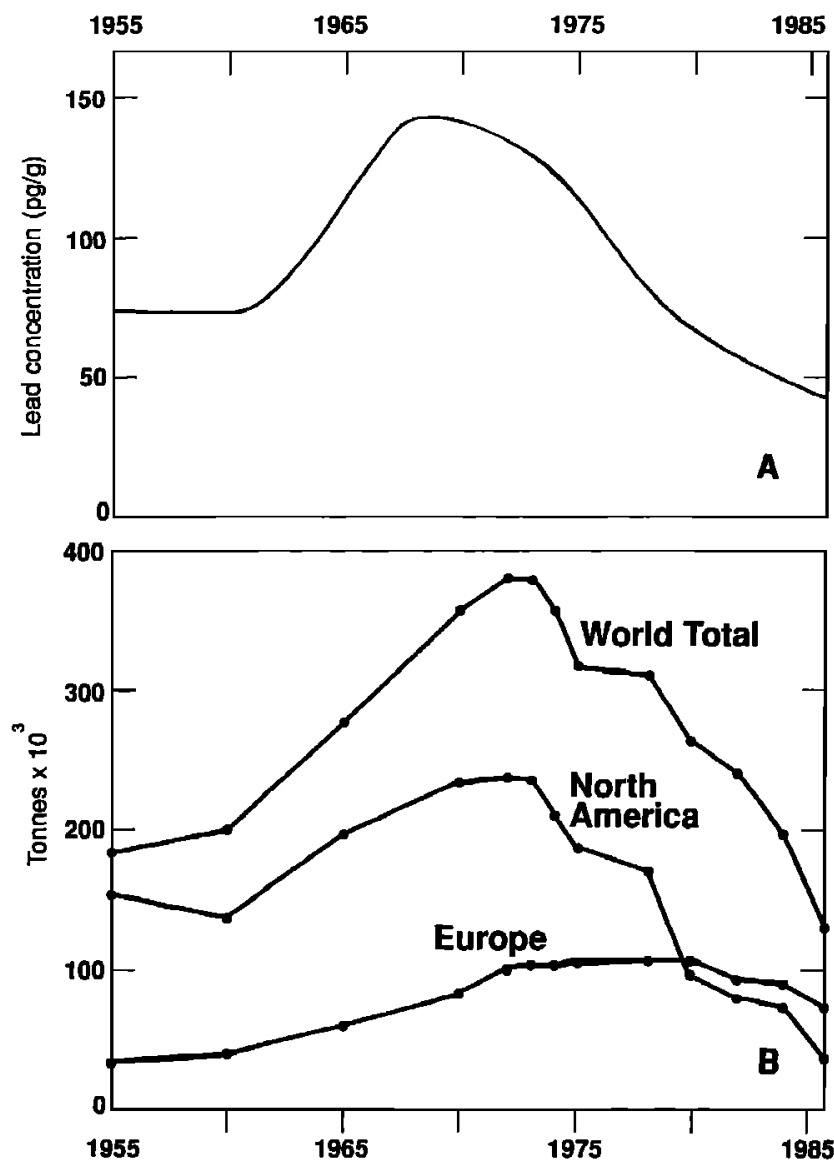

Figure 5. (a) Changes in $\mathrm{Pb}$ concentration in snow/ice at Summit, central Greenland, from 1955 to 1986 (splinesmoothed cure). (b) Changes in $\mathrm{Pb}$ (in metric tons) used to manufacture $\mathrm{Pb}$ alkyl antiknock additives for gasoline during the same time period [Larbey and Bain, 1988]. It is estimated that $-70 \%$ of the amount of the lead content in the additive is emitted to the atmosphere through the exhaust pipe.

[Pacyna, 1989, 1991; Pacyna et al., 1993], although the largest part undoubtedly originates from the massive fall in the use of $\mathrm{Pb}$ alkyl additives in gasoline from the early 1970s [Nriagu, 1990]. This is illustrated in Figure 5, which shows the striking parallelism between the observed changes in $\mathrm{Pb}$ concentration in Summit snow from 1955 to 1986 and the reported world (in fact mostly northern hemisphere) consumption of additives during the same period [Larbey and Bain, 1988]. Both curves do peak nearly at the same time $(\sim 1970)$. Moreover, the relative changes are very similar (decrease by a factor of $\sim 4$ from 1970 to 1986).

This fall was due both to the pioneering work of Murozumi et al. [1969] and to the generalization of catalytic exhaust pipes (these pipes cannot work when using leaded gasoline). It included two aspects. First, the increasing use of unleaded gasoline, which now represents virtually $100 \%$ of the gasoline sold in the United States and in Canada [Loranger and Zayed, 1994] and an ever increasing percentage of gasoline sold in European countries (48\% in France in 1994). Secondly, the very pronounced decline in the $\mathrm{Pb}$ content of leaded gasoline: in France, for instance, it is now almost 4 fold lower $(0.15 \mathrm{~g} / \mathrm{L}$ since June 1991) than it was 15 years ago $(0.55 \mathrm{~g} / \mathrm{L}$ in April 1976), with intermediate steps in January $1979(0.50 \mathrm{~g} / \mathrm{L})$, January $1981(0.40 \mathrm{~g} / \mathrm{L})$, and March $1989(0.25 \mathrm{~g} / \mathrm{L}))$.

\subsection{Comparison With Concentrations in Prehuman- Activities Ancient Holocene Ice}

Table 4 compares $\mathrm{Pb}, \mathrm{Zn}, \mathrm{Cd}$, and $\mathrm{Cu}$ concentrations observed in our oldest sample, dated on 1773, with those measured in Greenland ice 7760 years old, that is, Holocene ice deposited before man started to impact significantly on the atmosphere. These last data were obtained from the analysis of a 1286.5-m deep section of the 3028.8-m GRIP deep ice core drilled in 1990-1992 at Summit [Hong et al., 1994; S. Hong, personal communication, 1994].

For $\mathrm{Zn}, \mathrm{Cd}$, and $\mathrm{Cu}$, concentrations in 1773 appear to be very similar to those 7760 years ago, which shows that in the second half of the 18th century the troposphere of the remote Arctic areas of the northern hemisphere was still uncontaminated for these three metals. At that time, $\mathrm{Zn}, \mathrm{Cd}$, and $\mathrm{Cu}$ were still entirely derived from natural sources, mainly rock and soil dust [Hong et al., 1994; S Hong, personal communication, 1994]. When combined with the time series shown in Figure 3, the overall picture is, then, that the largescale pollution of the troposphere of the northern hemisphere started from $\sim$ the 1770 s for $\mathrm{Zn}$ and from $\sim$ the 1850 s for $\mathrm{Cd}$ and $\mathrm{Cu}$.

For $\mathrm{Pb}$, on the other hand, the situation is very different: concentrations measured in 1773 are found to be more than 1 order of magnitude higher than in ancient Holocene ice (Table 4). This clearly confirms for the first time the claim made long ago by $\mathrm{C}$. Patterson and his coworkers [Murozumi

Table 4. Summit, Central Greenland: Comparison of Heavy Metals Concentrations Measured in Ice Dated for 1773 (Second Half of the 18th Century, This Work) and in Prehuman-Activities Holocene Ice Dated for 7760 Years B.P.

\begin{tabular}{|c|c|c|c|c|c|}
\hline \multicolumn{2}{|c|}{ Age of Ice, Years } & \multicolumn{4}{|c|}{ Measured Concentrations, pg/g } \\
\hline Calendar & B.P. & $\mathrm{Pb}$ & $\mathbf{Z n}$ & Cd & $\mathrm{Cu}$ \\
\hline 1773 A.D. & 222 & 7.6 & 16 & 0.27 & $\leq 2.8$ \\
\hline 5766 B.C. & 7760 & 0.55 & 23 & 0.25 & 1.7 \\
\hline
\end{tabular}

(from Hong et al. [1994] and S. Hong, personal communication, 1994). 


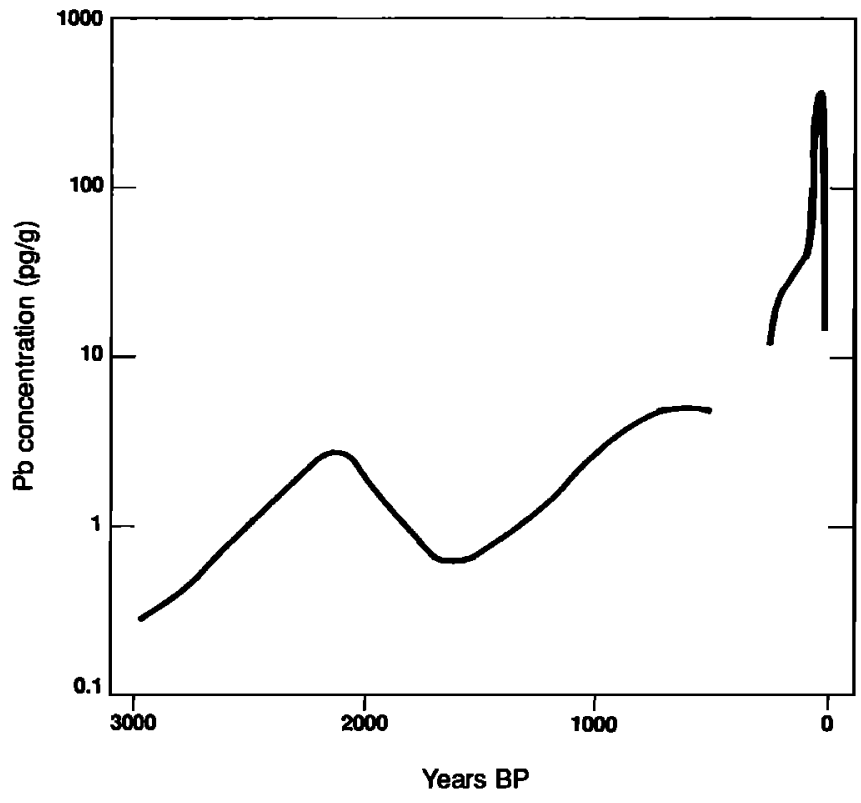

Figure 6. Changes in $\mathrm{Pb}$ concentrations in ice/snow at Summit, central Greenland, from 3000 years B.P. to 1992. Years 3000-470 B.P.: data from Hong et al. [1994]; years 1773-1992: this work. Note the logarithmic scale on the vertical axis.

et al., 1969; Patterson, 1980] that the troposphere of the remote areas of the northern hemisphere was already heavily contaminated with this toxic metal long before the onset of the Industrial Revolution. Actually, this large-scale pollution started as early as $\sim 3000$ years ago. This was recently evidenced by Hong et al. [1994] from the analysis of various sections of the 3028.8-m GRIP deep ice core whose age ranged from 3000 to 470 years B.P. (depths: 619.3 to $129.3 \mathrm{~m}$ ). It was evident from $\sim 2500$ to 1700 years B.P., that is, during the flourishing of the Greco-Roman civilization, as a consequence of anthropogenic $\mathrm{Pb}$ emissions to the atmosphere linked with the extensive Greek and Roman $\mathrm{Pb} / \mathrm{Ag}$ mining and smelting activities. During that period, $\mathrm{Pb}$ concentrations in Greenland ice reached values of $~$ $3 \mathrm{pg} / \mathrm{g}$ [Hong et al., 1994], which is $\sim 6$ fold above natural values and only 2.5 fold lower than the 1773 concentration value. After the fall of the Roman Empire, it declined down to values close to the natural ones. Finally, it started to increase again progressively from 1500 to $\mathbf{4 7 0}$ years ago, that is, during the Medieval and Renaissance times [Hong et al., 1994]. $\mathrm{Pb}$ concentration 470 years ago (i.e., in 1524) was close to $4 \mathrm{pg} / \mathrm{g}$, that is $\sim 2$ times lower than in 1773 .

The overall picture is, then, that the history of the large-scale pollution of the troposphere of the northern hemisphere during the past 3 millennia has been rather lively, with a succession of increases and decreases (Figure 6). Two maxima are observed in Figure 6: the first one around 2000 years ago, at the peak of Roman power and influence; the second one around 1970, at the peak of the use of $\mathrm{Pb}$ alkyl additives in gasoline. The amplitudeof these changes is much larger than that for any other pollutant species: the $\mathrm{Pb}$ concentration measured in Greenland snow in $1970(\sim 110 \mathrm{pg} / \mathrm{g}$, Figure 4) is about 200 times higher than in pre human activities Holocene ice $(0.55$ $\mathrm{pg} / \mathrm{g}$, Table 4).

\subsection{Past and Present-Day Atmospheric Deposition Fluxes to the Greenland Ice Sheet}

The past and present day atmospheric deposition fluxes of $\mathrm{Pb}, \mathrm{Zn}, \mathrm{Cd}$, and $\mathrm{Cu}$ at Summit can be estimated by combining the heavy metals concentrations measured in the snow or ice with the snow/ice accumulation rate of $23 \mathrm{~g} \mathrm{H}_{2} 0 \mathrm{~cm}^{-2} \mathrm{yr}^{-1}$ at Summit (a value which has remained essentially unchanged during the past few thousand years). We have made the calculations for different times (Table 5): 7760 years B.P., which gives the pre human activity Holocene fluxes; 1773, which corresponds to the onset of the first Industrial Revolution; 1850, which is the time when $\mathrm{Cd}$ and $\mathrm{Cu}$ concentrations started to increase; and 1992. In addition, Table 5 also presents the deposition fluxes for the 1960 s and 1970 s

Table 5. Heavy Metals Deposition Fluxes at Summit, Central Greenland

\begin{tabular}{lcccc}
\hline & \multicolumn{5}{c}{ Flux, $10^{-10} \mathrm{~g} \mathrm{~cm}^{-2} \mathrm{yr}^{-1}$} \\
\cline { 2 - 5 } Year & $\mathrm{Pb}$ & $\mathrm{Zn}$ & $\mathrm{Cd}$ & $\mathrm{Cu}$ \\
\hline & & & & \\
7760 B.P. & 0.13 & 5.3 & 0.06 & 0.39 \\
1773 & 1.8 & 3.7 & 0.06 & $\leq 0.64 \dagger$ \\
$1850 \ddagger$ & 3.5 & 7.0 & 0.06 & 0.53 \\
$1992 \ddagger$ & 3.9 & 12 & 0.18 & 1.7 \\
1960 s and & 25 & 20 & 0.41 & 2.2 \\
1970 s (maximum) & & & & \\
\hline
\end{tabular}

\footnotetext{
*Concentration values given by Hong et al [1994] and S. Hong, personal communication, 1994.

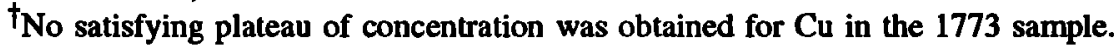
$\ddagger$ For 1850 and 1992 the concentration values used for the calculations are those given by the spline-smoothed curves shown in Figures 3 and 4.
} 
Table 6. Past and Present-Day Deposition Fluxes of Heavy Metals to the Greenland Ice Cap

\begin{tabular}{lcccc}
\hline & \multicolumn{5}{c}{ Flux, $\mathrm{yr}^{-1}$} \\
\cline { 2 - 5 } Year & $\mathrm{Pb}$ & $\mathrm{Zn}$ & $\mathrm{Cd}$ & $\mathrm{Cu}$ \\
\hline & & & & \\
7760 B.P. & 0.24 & 9.8 & 0.11 & 0.72 \\
1773 & 3.3 & 6.8 & 0.11 & $\leq 1.2$ \\
1850 & 6.5 & 13 & 0.11 & 1.0 \\
1992 & 7.2 & 22 & 0.33 & 3.1 \\
1960 s and & 46 & 37 & 0.75 & 4.1 \\
1970 s (maximum) & & & & \\
\hline
\end{tabular}

when the concentrations reached their maximum. The fluxes so calculated range from $0.06 \times 10^{-10} \mathrm{~g} \mathrm{~cm}^{-2} \mathrm{yr}^{-1}$ (Cd until 1850) to $25 \times 10^{-10} \mathrm{~g} \mathrm{~cm}^{-2} \mathrm{yr}^{-1}$ ( $\mathrm{Pb}$ in the early $\left.1970 \mathrm{~s}\right)$.

Extrapolation to the whole Greenland ice cap (surface of $1.4 \times 10^{6} \mathrm{~km}^{2}$; mean accumulation rate of $34.5 \mathrm{~g} \mathrm{H}_{2} 0 \mathrm{~cm}^{-2} \mathrm{yr}^{-1}$ ) would require that the deposition patterns are known for the different areas of the ice cap, which is not the case. Besides the Summit data, there are indeed only very few reliable heavy metals data for other locations in Greenland, which, moreover, are not for the same time periods [Murozumi et al., 1969; Wolff and Peel, 1988]. We have then assumed that the deposition patterns for heavy metals to the Greenland ice cap are similar to those for non sea-salt sulfate (nss sulfate) [Legrand, 1995]. For this compound, extensive data are now available for various areas of Greenland [Legrand, 1995]. They show that the nss sulfate deposition fluxes are correlated with the snow/ice accumulation rates. The mean annual deposition flux of nss sulfate to the Greenland ice cap was found to be $1.04 \times 10^{-6} \mathrm{~g} \mathrm{~cm}^{-2} \mathrm{yr}^{-1}$, that is, $\sim 1.3$ times the value for Summit $\left(0.8 \times 10^{-6} \mathrm{~g} \mathrm{~cm}^{-2} \mathrm{yr}^{-1}\right)$. The heavy metals deposition fluxes so obtained are given in Table 6. They range from $0.11 \mathrm{t} \mathrm{yr}^{-1}$ (Cd before 1850) up to $46 \mathrm{t} \mathrm{yr}^{-1}$ ( $\mathrm{Pb}$ in the early 1970s).

Finally, it is interesting to evaluate the cumulative anthropogenic deposition flux of heavy metals to the Greenland ice cap from 1773 to 1992 , that is, from the onset of the first Industrial Revolution to present. The calculations were made from the spline-smoothed curves shown in Figures 3 and 4 after subtracting the natural contribution estimated from the 7760 years B.P. sample. The cumulative deposition flux during this 220-year period is found to be $\sim 3200 \mathrm{t}$ for $\mathrm{Pb}$, which is 1 order of magnitude higher than the deposition (400 t) documented for the Greco-Roman times [Hong et al., 1994]. For $\mathrm{Zn}, \mathrm{Cd}$, and $\mathrm{Cu}$ the fluxes are $-2500,60$, and $200 \mathrm{t}$ respectively.

Acknowledgments. This work is a contribution of the Eurocore program funded by the Commission of European Communities and Switzerland within the framework of Cost 611. It was supported by the French Ministry of the Environment (grant 92295), the Institut National des Sciences de l'Univers, and the University Joseph Fourier of Grenoble. We thank C. Rado, R.J. Delmas, and F. Maupetit for their participation in field sampling.

\section{References}

Appelquist, H., K. O. Jensen, T. Sevel, and C. Hammer, Mercury in the Greenland ice sheet, Nature, 273, 657-659, 1978.

Barrie, L. A., Arctic air pollution: an overview of current knowledge, Atmos. Environ., 20, 643-663, 1986.

Boutron, C. F., and C. C. Patterson, Lead concentration changes in Antarctic ice during the Wisconsin/Holocene transition, Nature, 323, 222-225, 1986.

Boutron, C.F., A clean laboratory for ultralow concentration heavy metal analysis, Fresenius Z Anal. Chem. 337, 482-491, 1990

Boutron, C. F., U. Görlach, J. P. Candelone, M. A. Bolshov, and R. J. Delmas, Decrease in anthropogenic lead, cadmium and zinc in Greenland snows since the late 1960s, Nature, 353, 153156, 1991.

Boutron, C. F., J. P. Candelone, and S. Hong, Past and recent changes in the large scale tropospheric cycles of lead and other heavy metals as documented in Antarctic and Greenland snow and ice: a review, Geochim. Cosmochim. Acta, 58, 3217-3225, 1994.

Boutron, C. F., J. P. Candelone, and S. Hong, Greenland snow and ice cores: unique archives of the large scale pollution of the troposphere of the Northern Hemisphere for lead and other heavy metals, Sci. Total Environ., 160/161, 233-241, 1995.

Boyle, E. A., R. M. Sherrell, and M. P. Bacon, Lead variability in the western North Atlantic Ocean and central Greenland ice: implications for the search of decadal trends in anthropogenic emissions, Geochim. Cosmochim. Acta, 58, 3227-3238, 1994.

Candelone, J. P., S. Hong, and C. F. Boutron, An improved method for decontaminating polar snow or ice cores for heavy metal analysis, Anal. Chim. Acta, 299, 9-16, 1994.

Candelone, J. P., J. L. Jaffrezo, S. Hong, C. Pellone, C .I. Davidson and C. F. Boutron, Seasonal variations in heavy metal concentrations in present day Greenland snow, Earth Planet. Sci. Lett, in press, 1995.

Carr, R. A., and P. E. Wilkniss, Mercury in the Greenland ice sheet: further data, Science, 181, 843-844, 1973.

Colonial Geological Survey, Statistical Sunmary of the Mineral Industry. (Production, Imports and Exports), vols 1945-1951, Miner. Resour. Div., Her Majesty's Stationery Off., London, 1945-1951.

Cragin, J. H., M. M. Herron, and C. C. Langway Jr., The chemistry of 700 years of precipitation at Dye 3, Greenland, Res. Rep. 341, U.S. Army Cold Regions Res. Eng. Lab., Hanover, New Hampshire, 1975. 
Gillet, F., D. Donnou, C. Girard, A. Manouvrier, C. Rado, and G. Ricou, Ice core quality in electro-mechanical drilling, in Ice Drilling Technology, Rep. 84-34, edited by G. Holdsworth, K. C. Kuivinen, and J. H. Rand, U.S. Army Cold Regions Res. Eng. Lab., Hanover, New Hampshire, Rep. 84-34, 1984.

Görlach, U., and C. F. Boutron, Preconcentration of lead, cadmium, copper and zinc in water at the $\mathrm{pg} / \mathrm{g}$ level by nonboiling evaporation, Anal. Chim. Acta, 236, 391-388, 1990.

Görlach, U. and C. F. Boutron, Changes in heavy metals concentrations in Antarctic snows from 1940 to $1980, J$. Atmos.Chem. 14, 205-222, 1992.

Granjean, P., Health significance of organolead compounds, in Lead versus Health, edited by $M$. Rutter and $R$. Russell Jones, pp 179-189, John Wiley, New York, 1983.

Herron, M. M., C. C. Langway Jr., H. V. Weiss and J. H. Cragin, Atmospheric trace metals and sulfate in the Greenland ice sheet, Geochim. Cosmochim. Acta, 41, 915-920, 1977.

Hong, S., J .P. Candelone, C. C. Patterson and C. F. Boutron, Greenland ice evidence of hemispheric pollution for lead two millennia ago by Greek and Roman civilizations, Science, 265, 1841-1843, 1994.

Imperial Mineral Resources Bureau, The Mineral Industry of the British Empire and Foreign Countries. Statistical Summary (Production, Imports and Exports), vols 1913-1920, His Majesty's Stationery Off. London, 1913-1920.

Imperial Institute, The Mineral Industry of the British Empire and Foreign Countries. Statistical Summary (Production, Imports and Exports), vols 1920-1944, His Majesty's Stationery Off., London, 1920-1944.

Jaffe, D.,Cerundolo B., Rickers J., Stolzberg R. and A. Baklanov Deposition of sulfate and heavy metals in the Kola peninsula, Sci. Total Environ., 160/161, 127-134, 1995.

Larbey R. J. and J. R. Bain, Trends in the use of lead as a gasoline antiknock additive, paper presented at International Lead and Zinc Conference,The Associated Octel Company Limited, London, October 5-7, 1988.

Legrand, M., Sulphur-derived species in polar ice : a review, in Ice Core Studies of Global Biogeochemical Cycles, edited by R. J. Delmas, NATO-ARW Ser. I, Vol. 30, Kluwer, Dordrecht, pp. 91-120, 1995.

Lobinski, R., C. . Boutron, J. P. Candelone, S. Hong, J. SzpunarLobinska, and F. C. Adams, Speciation analysis of organolead compounds in Greenland snow at the femtogram-per-gram level by capillary gas chromatography/atomic emission spectrometry, Anal. Chem., 65, 2510-2515, 1993.

Lobinski, R., C. F. Boutron, J. P. Candelone, S. Hong, J. SzpunarLobinska, and F. C. Adams, Present century snow core record of organolead pollution in Greenland, Environ. Sci. Technol., 28, 1467-1471, 1994.

Loranger, S., and J. Zayed, Manganese and lead concentrations in ambient air and emission rates from unleaded and leaded gasoline between 1981 and 1992 in Canada: a comparative study, Atmos. Environ., 28, 1645-1651, 1994.

Möller, D., Estimation of the global man-made sulphur emission, Atmos. Environ., 18, 19-27, 1984.

Murozumi, M., T. J. Chow and C. C. Patterson, Chemical concentrations of pollutant lead aerosols, terrestrial dusts and sea salts in Greenland and Antarctic snow strata, Geochim. Cosmochim. Acta, 33, 1247-1294, 1969.

National Environmental Research Council, Statistical Summary of the Mineral Industry. World Production, Imports and Exports, vols 1952-1970, Inst. of Geol. Sci. Miner. Resour. Div., Her Majesty's Stationery Off., London, 1952-1970.

National Environmental Research Council, Statistics. Production: Exports, Imports, vols 1970-1990, Inst. of Geol. Sci. Miner.
Stat. and Econ. Unit, Her Majesty's Stationery Off., London, 1970-1990.

$\mathrm{Ng}$, A. and C. C. Patterson, Natural concentrations of lead in ancient Arctic and Antarctic ice, Geochim. Cosmochim. Acta, 45, 2109-2121, 1981.

Nriagu, J. O. (Ed.), Biogeochemistry of Lead in the Environment, Elsevier, New York, 1978.

Nriagu, J. O. (Ed.), Zinc in the Environment, John Wiley, New York, 1979a.

Nriagu, J. O. (Ed.), Cadmium in the Environment, Wiley, New York, 1979b.

Nriagu, J. O. (Ed.), Copper in the Environment, Wiley, New York, 1979c.

Nriagu, J. O., Global inventory of natural and anthropogenic emissions of trace metals to the atmosphere, Nature, 279, 409 . 411, 1979d.

Nriagu, J. O., A global assessment of natural sources of atmospheric trace metals, Nature, 338, 47-49, 1989.

Nriagu, J .O., The rise and fall of leaded gasoline, Sci. Total Environ., 92, 13-28, 1990.

Nriagu, J .O. and J. M. Pacyna, Quantitative assessment of worldwide contamination of air, water and soils by trace metals, Nature, 323, 134-139, 1988.

Pacyna, J. M., Technological parameters affecting atmospheric emissions of trace elements from major anthropogenic sources, in Control and Fate of Atmospheric Trace Metals, edited by J. M. Pacyna and B. Ottar, pp. 15-31, Kluwer Academic, Norwell, Mass., 1989.

Pacyna, J. M., Emission Factors of Atmospheric $\mathrm{Cd}, \mathrm{Pb}$ and $\mathrm{Zn}$ for Major Source Categories in Europe in 1950 through 1985, Rep. OR 30-91, Norw. Inst. for Air Res., Lillestrom, Norway, 1991.

Pacyna, J. M., Emissions of pollutants and their control, in Topics in Atmospheric and Interstellar Physics and Chemistry, edited by C. F. Boutron, pp. 135-159, Les Editions de Physique, Paris, 1994.

Pacyna, J. M., E. Voldner, T.F. Bidleman, G. Evans and G.J. Keeler, Emissions, atmospheric transport and deposition of heavy metals and persistent organic pollutants, in Proceedings of the 1st Workshop on Emissions and Modelling of Atmospheric Transport of Persistent Organic Pollutants and Heavy Metals, edited by J.M. Pacyna, E. Voldner, G.J. Keeler and G. Evans, pp. 45-137, EMEP-CCC Rep. 7/93, Norw. Inst. for Air Res., Lillestrom, Norway, 1993.

Patterson, C. C., An alternative perspective - Lead pollution in the human environment: origin, extent and significance, in Lead in the Human Environment, pp. 265-349, Natl. Acad. of Sci., Washington, D. C., 1980.

Patterson, C. C. and D. M. Settle, The reduction of orders of magnitude errors in lead analysis of biological materials and natural waters by evaluating and controlling the extent and sources of industrial lead contamination introduced during sample collection and analysis, in Accuracy in Trace Analysis, edited by P. La FLeur, Natl. Bur. Stand. Spec. Publ. 422, 321$351,1976$.

Paulsen, P. J., E. S. Beary, D. S. Bushee and J. R. Moody, Inductively coupled plasma mass spectrometric analysis of ultrapure acids, Anal. Chem., 60, 971-975, 1988.

Peel, D. A., Trace metals and soot in ice cores, in The Environmental Record in Glaciers and Ice Sheets (Dahlem Konferenzen), edited by H. Oeschger and C. C. Langway Jr., pp. 207-223, John Wiley, New York, 1989.

Rosman, K. J. R., W. Chisholm, C. F. Boutron, J. P. Candelone and $U$. Görlach, Isotopic evidence for the sources of lead in Greenland snows since the late 1960s, Nature, 362, 333-335, 1993. 
Rosman, K. J. R., W. Chisholm, C. F. Boutron, J. P. Candelone and $\mathrm{S}$. Hong, Isotopic evidence to account for changes in the concentration of lead in Greenland snow between 1960 and 1988, Geochim. Cosmochim. Acta, 58, 3265-3269, 1994.

Rosman, K. J. R., W. Chisholm, C. F. Boutron, J. P. Candelone, and $S$. Hong, The changing isotopic composition of lead in snow deposited in central Greenland since the 18th century, Earth Planet. Sci. Lett., in press, 1995.

Savarino, J., C. F. Boutron and J. L. Jaffrezo, Short-term variations of $\mathrm{Pb}, \mathrm{Cd}, \mathrm{Zn}$ and $\mathrm{Cu}$ in recent Greenland snow, Atmos. Environ. 28, 1731-1737, 1994.

Taylor, S. R. and S. M. McLennan, The Continental Crust: its composition and evolution, Blackwell, Cambridge, Mass., 1985.

Thomas, V. and T. G. Spiro, Emissions and exposure to metals: cadmium and lead, in Industrial Ecology and Global Change, edited by R. Socolow, C. Andrew, F. Berkhout, and V. Thomas, pp. 297-317, Cambridge Univ. Press, New York, 1994.

U.S. Bureau of Mines, Mineral Yearbooks, vols 1930-1990, Washington, D. C., 1930-1990.

Van Cleuvenbergen, R. J. A. and F. C. Adams, Organolead compounds, in Handbook of Environmental Chemistry, edited by O. Hutzinger, Springer-Verlag, New York, 1990.

Vandal, G. M., W. F. Fitzgerald, C. F. Boutron, and J. P. Candelone, Variations in mercury deposition to Antarctica over the past 34,000 years, Nature, 362, 621-623, 1993.

Weiss, H. V., M. Koide, and E. D. Goldberg, Mercury in the Greenland ice sheet: evidence of recent input by man, Science, 174, 692-694, 1971a.
Weiss, H. V., M. Koide, and E. D. Goldberg, Selenium and sulfur in a Greenland ice sheet: relation to fossil fuel combustion, Science, 172, 261-263, $1971 \mathrm{~b}$.

Weiss, H. V., K. Bertine, M. Koide, and E. D. Goldberg, The chemical composition of a Greenland glacier, Geochim. Cosmochim. Acta, 39, 1-10, 1975.

Wolff, E. W., Signals of atmospheric pollution in polar snow and ice, Antarct. Sci., 2, 189-205, 1990.

Wolff, E. W., and D. A. Peel, The record of global pollution in polar snow and ice, Nature, 313, 535-540, 1985.

Wolff, E. W., and D.A. Peel, Concentrations of cadmium, copper, lead and zinc in snow from near Dye 3 in south Greenland, Ann. Glaciol., 10, 193-197, 1988.

Wolff, E. W. and E. D. Suttie, Antarctic snow record of southern hemisphere lead pollution, Geophys. Res. Lett., 21, 781-784, 1994.

C.F. Boutron, J.P. Candelone and S. Hong, Laboratoire de Glaciologie et Géophysique de l'Environnement du CNRS, 54, rue Molière, B.P. 96, 38402 Saint Martin d'Hères, France.

C. Pellone, Centre de Recherche et d'Essais des Machines Hydrauliques de Grenoble, Domaine Universitaire, B.P. 95 X, 38402 Saint Martin d'Hères, France.

(Received September 21, 1994; revised February 9, 1995; accepted February 24, 1995.) 